\title{
Cements based on kaolinite waste
}

\author{
Rosario García Giménez ${ }^{1}$, Raquel Vigil de la Villa Mencía ${ }^{1}$, Moises Frías ${ }^{2}$, Sagrario Martínez Ramírez ${ }^{3}$, \\ Iñigo Vegas Ramiro ${ }^{4}$, and Lucía Fernández Carrasco 5 \\ ${ }^{1}$ Dpto. Geología y Geoquímica, Facultad de Ciencias, Geomateriales Associated Unit CSIC-UAM, \\ Universidad Autónoma, 28049 Madrid, Spain \\ ${ }^{2}$ Eduardo Torroja Institute for Construction Sciences (IETcc-CSIC), 28033 Madrid, Spain \\ ${ }^{3}$ Institute for the Structure of Matter (IEM-CSIC), 28006 Madrid, Spain \\ ${ }^{4}$ Tecnalia, Construction Unit, 48160 Derio, Spain \\ ${ }^{5}$ Centre de Recerca en Nanoenginyeria (CRnE), Universitat Politècnica de \\ Catalunya - Barcelona TECH, 08028 Barcelona, Spain
}

Correspondence: Rosario García-Giménez (rosario.garcia@uam.es)

Received: 26 May 2018 - Revised: 18 July 2018 - Accepted: 23 July 2018 - Published: 10 August 2018

\begin{abstract}
The cement industry involves high-energy consumption that generates high $\mathrm{CO}_{2}$ emissions into the atmosphere. Environmental concerns can be addressed by replacing parts of Portland cement clinkers with pozzolanic materials in mortars and concrete. Slag, fly ash and silica fume are materials considered for the planned replacement. Research studies on clay minerals, such as kaolinite, are being followed with special attention by the scientific community and the cement industry. It is well known that these minerals require an activation process to transform kaolinite $(\mathrm{K})$ into metakaolinite $(\mathrm{MK})$. MK is an amorphous material from the transformation of $\mathrm{K}$ with high pozzolanic activity, which is its capacity to react with the portlandite released during the hydration of Portland cement, generating compounds such as $\mathrm{C}-\mathrm{S}-\mathrm{H}$ gels and some aluminum-phase hydrates. One of the MK production methods is heat treatment controlled by kaolinite at temperatures in the range of $600-900^{\circ} \mathrm{C}$. Different residues have been used (coal mining, paper sludge and waste from a drinking water treatment plant) activated at $600^{\circ} \mathrm{C}$ for $2 \mathrm{~h}$ to elaborate blended cements. Due to their good behaviour as future eco-efficient additions, this research is a study by $\mathrm{x}$-ray fluorescence (XRF), $\mathrm{x}$-ray diffraction (XRD) and scanning electron microscopy (SEM) of their influence on the performances of blended cement mixtures (binary and ternary one), with substitutions of pozzolan ratio at 28 days of hydration. The porosity of pozzolanic cements decreases because of the formation of hydrated phases during pozzolanic reaction.
\end{abstract}

\section{Introduction}

The cement industry traditionally uses in its production process a huge quantity of waste and by-products in different stages: alternative fuel, activated drinking water treatment waste, raw materials and/or pozzolanic additions in order to reduce the environmental impact. The use of cementitious materials in the manufacture of eco-efficient cements is focused on industrial waste. Research studies on clay minerals, such as kaolinite $(\mathrm{K})$, are being followed with special attention by the scientific community and the cement industry (Rios et al., 2009; Vejmelkova et al., 2010; Janotka et al., 2010; Ptacek et al., 2014; Pesce et al., 2014; Frías et al., 2014; García-Giménez et al., 2016). It is well known that these minerals require an activation process to transform $\mathrm{K}$ into metakaolinite (MK), which is a highly pozzolanic product included in the European Community legislation (UNEEN 197-1, 2011).

A way to obtain MK is through the activation of K-based industrial waste. Vigil et al. (2007) and Frías et al. (2008) reported that MK obtained from paper sludge, calcinated at temperatures between 650 and $700^{\circ} \mathrm{C}$ for $2 \mathrm{~h}$, has similar pozzolanic activity as other highly pozzolanic additions, such as commercial MK or silica fume, improving the performances of blended cements (Bai et al., 2003; Rodríguez et al., 2009). Another interesting research line to obtain recycled MK is the recycling of coal mining waste or activated drinking waste (Frías et al., 2014). These residues come from 
the processes of extracting and washing coal, and they are mainly composed of carbon and clay minerals (kaolinite).

The sludge generated in drinking water treatment plants is among this class of waste in significant quantities, which are normally taken to landfills for disposal with the ensuing environmental problems (Kynci, 2008).

The reuse of this drinking water sludge as a pozzolanic addition in the manufacture of new eco-efficient blended cements is a promising future alternative due to its silicoaluminous properties. The few works of reference in this area are by Goncalves et al. (2004), who used blended cement mortars with substitutions of $5 \%, 10 \%$ and $20 \%$ of total cement content for a (kaolinite-based) drinking water treatment sludge from Portugal, and by Husillos et al. (2010), who characterised the behaviour of blended cement mortars with $10 \%-30 \%$ of atomised sludge (without kaolinite) of Spanish origin.

Blended cements properties depend on the nature and composition $\left(\mathrm{CaO} / \mathrm{SiO}_{2}\right.$ ratio) of activated pozzolans. The research carried out in this paper included the study of scientific aspects (pozzolanicity, mineralogical phases), physical (porosity) and mechanical properties (compressive strength), and the relationship between them.

Due to their good behaviour as future eco-efficient additions, this paper conducts a detailed study of their influence on the performances of blended cement mixtures (binary and ternary), with substitutions of $10 \%$ and $20 \%$ pozzolan at 28 days of hydration.

\section{Materials and experimental procedure}

\subsection{Materials}

The materials used in this work are the following.

- Coal mining waste activated at $600^{\circ} \mathrm{C}$ during $2 \mathrm{~h}$ (ACW).

The coal mining waste was a coal gangue waste (CW) deposited in a landfill at an opencast mine and collected by a Spanish coal group (Sociedad Anonima Hullera Vasco-Leonesa) in the Leon province, Spain. The coal mining waste was activated at $600^{\circ} \mathrm{C}$ for $2 \mathrm{~h}$ of retention in an electric laboratory furnace (the new samples are called ACW from now on), as this is the best activation temperature from an economic and energy point of view (Frías, 2012). ACW was ground in an agate mortar and pestle to obtain particle sizes less than $63 \mu \mathrm{m}$.

- Activated paper sludge $\left(600^{\circ} \mathrm{C}\right.$ during $\left.2 \mathrm{~h}\right)+$ fly ash (APS + FA).

APS was obtained by controlled calcination of paper sludge in our laboratory by means of an electric furnace at $600{ }^{\circ} \mathrm{C}$ for $2 \mathrm{~h}$, as described in previous work (García et al., 2010). The paper sludge (PW) was provided by Holmen Paper Madrid. This treatment eliminates organic material, achieves the total dehydroxylation of $\mathrm{K}$ into MK and avoids an excessive decarbonation of calcite, which could result in a significant amount of quicklime, a compound well known for its expansive property during hydration. APS and FA pozzolans were previously mixed with a ratio of $1: 1$ by weight, and the chemical composition of the mix is shown in Table 1. The FA met the requirements of American Society of Testing Materials (ASTM) Class F and the EN-UNE 450 specifications (UNE-EN 450-1, 2013): $\mathrm{SiO}_{2}+\mathrm{Al}_{2} \mathrm{O}_{3}+\mathrm{Fe}_{2} \mathrm{O}_{3}$ contents higher than $70 \%$ and low $\mathrm{CaO}$ content.

- The starting waste (SW) for this research came from a Venezuelan drinking water treatment plant (Embalse La Mariposa) located at $8 \mathrm{~km}$ from Caracas. Its water content was initially around $92 \%$. After drying, the ASW was activated at $600^{\circ} \mathrm{C}$ for $2 \mathrm{~h}$ of retention in an electric laboratory furnace at a heating rate of $20^{\circ} \mathrm{C} \mathrm{min}^{-1}$, following the indications of a previous paper (Frías et al., 2012) in which these conditions were selected as the suitable activation conditions from an economic and energy point of view. The activated waste (ASW), when cooled to room temperature in a desiccator, showed a reddish coloration. The sample was ground in an agate mortar and pestle and then sieved through a $63 \mu \mathrm{m}$ mesh.

- Ordinary Portland cement (OPC).

The cement was a commercially available Ordinary Portland cement (OPC) classified as CEM I 52.5R supplied by Financiera y Minera (Italcementi group).

- Blended cements.

Partial replacements of OPC with $10 \%$ and $20 \%$ pozzolan (ACW, APS + FA or AW) were made. The corresponding OPC-pozzolan mixtures were called 100/0, $90 / 10$ and $80 / 20$. Pastes were prepared at a demineralised water-to-binder ratio of 0.5 . After mixing, a series of six prisms $1 \times 1 \times 6 \mathrm{~cm}$ were moulded and compacted by vibration. After 1 day at $>95 \%$ of relative humidity (RH) the samples were demoulded and cured at $21^{\circ} \mathrm{C}$ under $>95 \% \mathrm{RH}$ in sealed containers for a period of 28 days from mixing.

\subsection{Experimental procedure}

The chemical composition of the samples was determined by X-ray fluorescence (XRF) using a Philips PW1480 dispersive energy spectrophotometer, Sc/Mo anode, in working conditions of $80 \mathrm{kV}$ and $35 \mathrm{~mA}$.

Mineralogical analyses were carried out by X-ray diffraction (XRD) using a Siemens D-5000 analytical powder diffractometer with an automatic divergence slit, graphite monochromator and $\mathrm{Cu}-\mathrm{K}-\alpha$ radiation. The XRD data were 
Table 1. Mineralogical composition by XRD of products from coal mining $(\mathrm{CW}, \mathrm{ACW}$ and after 28 days of reaction in the ACW-lime system).

\begin{tabular}{lrrr}
\hline Minerals (\%) & CW & ACW & $\begin{array}{r}\text { ACW-lime } \\
\text { 28 days }\end{array}$ \\
\hline Mica & 20 & 14 & n.d. \\
Kaolinite & 14 & n.d. & n.d. \\
Quartz & 35 & 35 & 35 \\
Calcite & 17 & 13 & 16 \\
LDH & n.d. & n.d. & 6 \\
$\mathrm{C}_{4} \mathrm{AH}_{13}$ & n.d. & n.d. & 3 \\
Stratlingite & n.d. & n.d. & 14 \\
Amorphous material & 14 & 38 & 26 \\
$R_{B}$ & 10.20 & 9.57 & 8.32 \\
$X^{2}$ & 5.80 & 4.79 & 4.47 \\
\hline
\end{tabular}

The notation "n.d." indicates not detected.

collected in the angular range $3^{\circ} \leq 2 \theta \leq 65^{\circ}$ with step $0.03^{\circ}$ and counting time $3 \mathrm{~s}$. The current and voltage intensities applied to the generating X-ray tube were $30 \mathrm{~mA}$ and $40 \mathrm{~kW}$ with divergence and receipt splits of 1 and $0.18^{\circ}$, respectively. The complete identification and quantification were determined by the Rietveld method (De la Torre et al., 2001) using rutile as a standard sample.

The textural study of the material was accomplished using an electronic microscopy sweep with a Philips XL 30 and a Wolfram source. The powder samples were fixed to the metallic slide through a graphite plate (BIO-RED SC502). The results were obtained through chemical analyses by EDX with a silicon-lithium detector and analyser DX41. Data shown in the tables are the average value of 10 measurements carried out in different fields.

\section{Results and discussion}

\subsection{Characterisation of waste and activated waste}

1. Coal mining

Quartz, calcite and phyllosilicates (mica illite type and kaolinite) compose the coal mining starting waste (CW). In addition, the coal mining waste activated at $600^{\circ} \mathrm{C}$ during $2 \mathrm{~h}(\mathrm{ACW})$ is mainly by low quartz, micas and calcite (kaolinite peaks disappear after calcination) (Table 1). The reaction products after 28 days are layered double hydroxides (LDHs; formed from the tetrahedral and octahedral layers), stratlingite and the initial formation of $\mathrm{C}_{4} \mathrm{AH}_{13}$. The chemical composition is in Table 2.

\section{Paper sludge waste}

The mineralogical composition of paper sludge waste (PW) is calcite and phyllosilicates (talc and kaolinite).
Table 2. Chemical characterisation by XFR of the materials in this work.

\begin{tabular}{lrrrrrrrr}
\hline Oxide (\%) & APS & FA & APS-FA & CW & ACW & SW & ASW & OPC \\
\hline $\mathrm{SiO}_{2}$ & 13.9 & 55.7 & 34.8 & 49.8 & 56.6 & 36.2 & 41.5 & 20.2 \\
$\mathrm{Al}_{2} \mathrm{O}_{3}$ & 8.3 & 24.0 & 16.2 & 21.7 & 25.3 & 29.5 & 33.6 & 4.3 \\
$\mathrm{Fe}_{2} \mathrm{O}_{3}$ & 0.5 & 4.8 & 2.7 & 4.1 & 4.6 & 10.0 & 11.1 & 2.5 \\
$\mathrm{CaO}$ & 47.1 & 2.2 & 24.7 & 3.8 & 4.2 & 1.0 & 0.4 & 63.4 \\
$\mathrm{MgO}$ & 1.6 & 0.9 & 1.3 & 0.6 & 0.8 & 1.2 & 1.5 & 2.2 \\
$\mathrm{SO}_{3}$ & n.d. & 0.9 & 0.4 & 0.2 & 0.3 & 0.3 & 0.3 & 3.5 \\
$\mathrm{~K}_{2} \mathrm{O}$ & 0.3 & 2.2 & 1.2 & 2.7 & 3.1 & 3.3 & 3.7 & 0.9 \\
$\mathrm{Na}_{2} \mathrm{O}$ & 0.2 & 0.5 & 0.3 & 0.1 & 0.2 & 0.8 & 1.0 & 0.3 \\
$\mathrm{TiO}_{2}$ & 0.3 & 0.7 & 0.5 & 1.1 & 1.2 & 1.2 & 1.4 & 0.2 \\
$\mathrm{P}_{2} \mathrm{O}_{5}$ & 0.2 & 0.3 & 0.2 & 0.1 & 0.1 & 0.7 & 0.7 & 0.1 \\
$\mathrm{MnO}$ & n.d. & n.d. & n.d. & 0.1 & 0.1 & 0.4 & 0.4 & n.d. \\
$\mathrm{LOI}$ & 26.7 & 7.6 & 17.1 & 15.1 & 3.1 & 15.3 & 3.3 & 2.0 \\
\hline
\end{tabular}

The notation "n.d." indicates not detected. LOI: loss of ignition.

FA is formed by quartz, mullite and hematite. In the activated paper sludge $\left(600^{\circ} \mathrm{C}\right.$ for $\left.2 \mathrm{~h}\right)(50 \mathrm{APS}+50 \mathrm{FA})$ the main crystalline compounds are talc, calcite, mullite, quartz and hematite (Table 3); the peaks for the $\mathrm{K}$ are no longer present after calcination. In the reaction after 28 days LDHs are shown. The chemical composition is given in Table 2 .

\section{Ordinary Portland cement (OPC)}

The main crystalline compounds of the OPC are alite $\left(42 \% \mathrm{C}_{3} \mathrm{~S}\right)$, belite $\left(28 \% \mathrm{C}_{2} \mathrm{~S}\right), 21 \% \mathrm{C}_{3} \mathrm{~A}$ and brownmillerite $\left(9 \% \mathrm{C}_{4} \mathrm{AF}\right)$; the chemical composition appears in Table 2.

\section{SW}

SW was mainly composed of $\mathrm{SiO}_{2}(36 \%), \mathrm{Al}_{2} \mathrm{O}_{3}$ $(29 \%)$ and $\mathrm{Fe}_{2} \mathrm{O}_{3}(10 \%)$, followed by $\mathrm{K}_{2} \mathrm{O}, \mathrm{MgO}$ and $\mathrm{TiO}_{2}$ with contents below $4 \%$, and the rest of the oxides were below $1 \%$ (Table 2). The SW sample presented a total organic carbon content of $2.3 \%$, which was due to the presence of colloidal or dissolved organic matter in water. The mineralogical composition obtained by XRD (Table 4) shows the presence of phyllosilicates $2: 1$ (muscovite), phyllosilicates $1: 1$ (kaolinite), quartz, calcite, feldspars and hematite. In the reaction products after 28 days $\mathrm{C}_{4} \mathrm{AH}_{13}$ did not appear and of the LDHs only stratlingite was present.

The Frattini method, described in European Standard UNE-EN 196-5, was employed to determine the pozzolanicity activity of the blended cements. The test involves hydrothermal curing of the blended cements for 8 and 15 days at $40{ }^{\circ} \mathrm{C}$ and $100 \% \mathrm{RH}$. At the end of the curing period, the suspensions were analysed for $\mathrm{Ca}$ content and alkalinity. Each mixture was tested twice and the mean values are reported. Comparisons are made using the solubility curve of $\mathrm{Ca}(\mathrm{OH})_{2}$ (UNE-EN 196-5, 2011). 
Table 3. Mineralogical composition by XRD of products from coal mining (PW, APS, FA, 50APS-50FA and after 28 days of reaction in the 50APS-50FA-lime system).

\begin{tabular}{lrrrrr}
\hline Minerals (\%) & PW & APS & FA & $\begin{array}{r}\text { 50APS- } \\
\text { 50FA }\end{array}$ & $\begin{array}{r}\text { 50APS- } \\
\text { 50FA-lime } \\
\text { 28 days }\end{array}$ \\
\hline Talc & & & & & n.d. \\
Kaolinite & 3 & 6 & n.d. & 3 & n.d. \\
Quartz & 8 & n.d. & n.d. & n.d. & 15 \\
Calcite & n.d. & n.d. & 31 & 15 & 20 \\
Mullite & 78 & 82 & n.d. & 41 & 12 \\
Hematite & n.d. & n.d. & 28 & 12 & 6 \\
LDH & n.d. & n.d. & 26 & 12 & 16 \\
Amorphous material & n.d. & n.d. & n.d. & n.d. & 31 \\
$R_{B}$ & 11 & 12 & 15 & 17 & 7.52 \\
$X^{2}$ & 10.20 & 9.57 & 10.49 & 11.36 & 4.99 \\
\hline
\end{tabular}

The notation "n.d." indicates not detected.

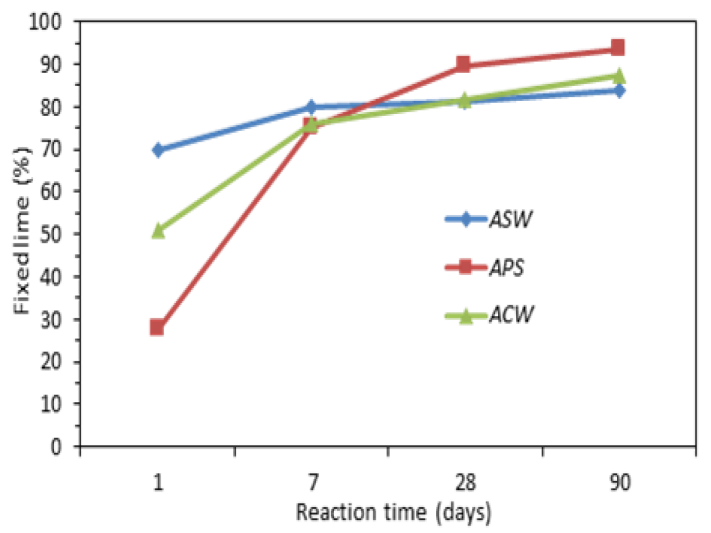

Figure 1. Evolution of the pozzolanic activity from the activated products.

\subsection{Pozzolanicity of blended cements}

The results obtained by the Frattini test for all blended cement pastes and for the reference cement paste at 15 days show that the only cement that could be considered as pozzolanic cement (Type CEM IV), according to the existing standard, is the cement paste elaborated with $20 \%$ APS + FA, but not at 8 days (Fig. 1). However, this waste presents pozzolanic activity when analysed in a pure pozzolan$\mathrm{Ca}(\mathrm{OH})_{2}$ system (Rodríguez et al, 2009).

\subsection{Mechanical properties}

\subsubsection{Compressive strength of blended cements}

Figure 2 shows compressive strength at 2 and 28 days (average of six specimens) for all the studied blended cements and the reference cement. All the blended cements have a lower compressive strength than OPC at 2 days of hydration due to moderate pozzolanic activity. ACW blended cement pastes exhibited slightly higher compressive strength than the OPC

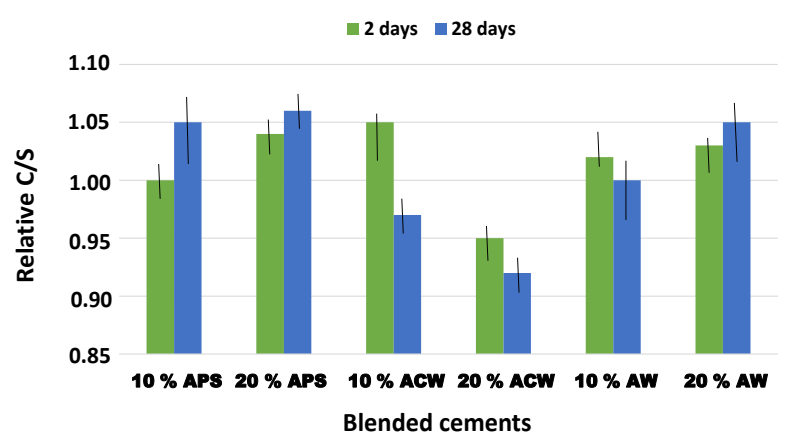

Figure 2. Relative compressive strength $(\mathrm{C} / \mathrm{S})$ of blended cements at 2 and 28 days.

Table 4. Mineralogical composition by XRD of products from coal mining (SW, ASW and after 28 days of reaction in the ASW-lime system).

\begin{tabular}{lrrr}
\hline Minerals (\%) & SW & ASW & $\begin{array}{r}\text { ASW-lime } \\
28 \text { days }\end{array}$ \\
\hline Mica & 32 & 39 & 18 \\
Kaolinite & 8 & n.d. & n.d. \\
Quartz & 9 & 9 & 9 \\
Calcite & 12 & 12 & 13 \\
Feldspars & 15 & 15 & 15 \\
Hematite & 8 & 8 & 8 \\
Stratlingite & n.d. & n.d. & 15 \\
Amorphous material & 16 & 17 & 22 \\
$R_{B}$ & 14.19 & 10.62 & 9.47 \\
$X^{2}$ & 6.47 & 5.29 & 5.42 \\
\hline
\end{tabular}

The notation "n.d." indicates not detected.

paste at 28 days. In pastes containing APS + FA, the compressive strength is lower at this age for $10 \%$ addition, probably due to the reactivity of FA being slower than MK-based pozzolans; however, the value for $20 \%$ replacement is very close to that obtained for OPC paste.

\subsubsection{Total porosity of blended cements}

The total porosity of blended cements is directly related to the compression strength results of the pastes, as can be seen in Fig. 2; porosity decreases from 2 to 28 days of curing as compressive strength increases, which decreases as a consequence of the formation of hydrated phases during pozzolanic reaction. $\mathrm{C}-\mathrm{S}-\mathrm{H}$ gels appeared in all waste. APS + FA waste shows LDH compounds and $\mathrm{C}-\mathrm{S}-\mathrm{H}$ gels (Fig. 3a); the same compounds are present in the ACW (Fig. 3b) and stratlingite (Fig. 3c). The ASWs are micas, stratlingite and $\mathrm{C}-\mathrm{S}-\mathrm{H}$ gels (Fig. 3d). Due to the reduction of pores and because of the growth of hydrated compounds that have hydraulic properties, the compressive strength increases (Rodríguez et al., 2009). OPC samples are less porous than 

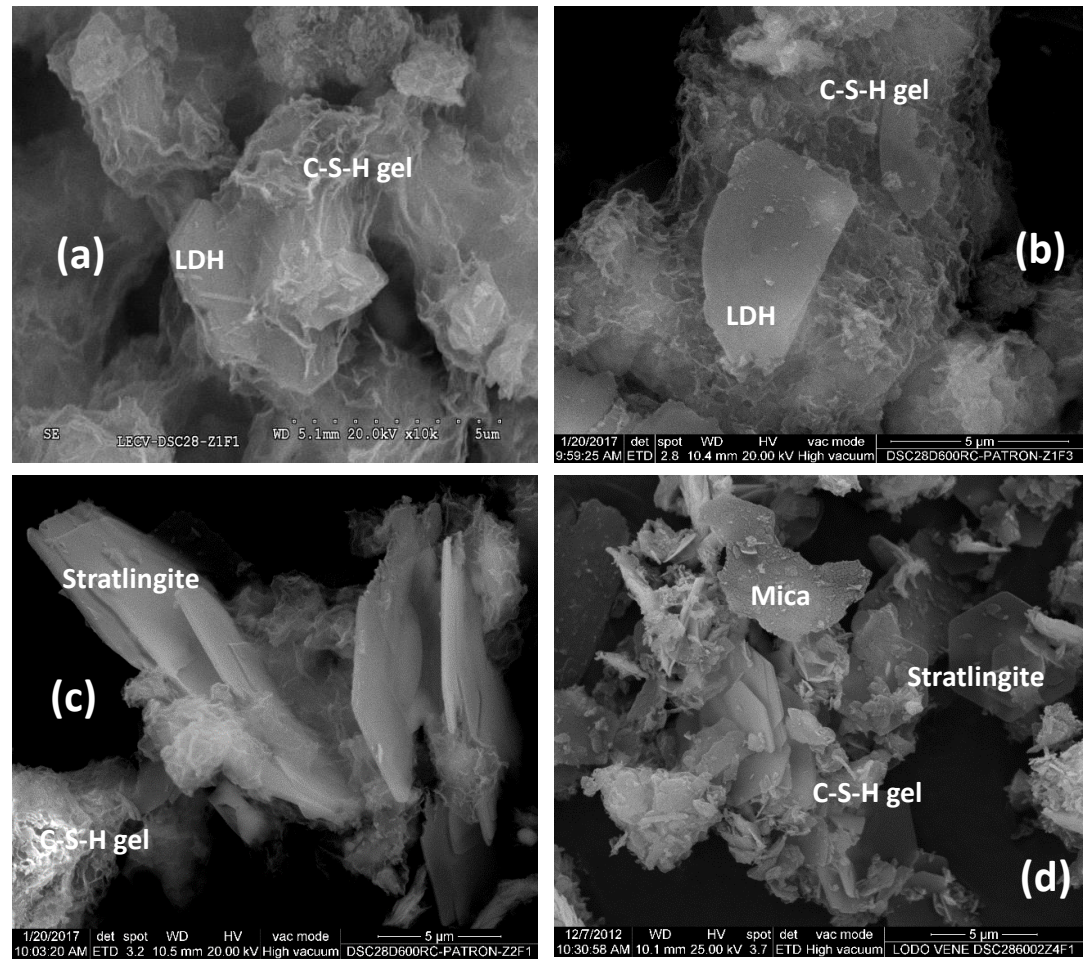

Figure 3. (a) LDH compounds and C-S-H gels from APS +FA in ACW. (b) LDH compounds and C-S-H gels from ACW. (c) Stratlingite and C-S-H gels from ACW. (d) Mica, stratlingite and C-S-H gels from ASW.

Table 5. Chemical analysis by EDX of the phases at 28 days.

\begin{tabular}{lrrrrr}
\hline Oxides (\%) & $\mathrm{C}_{2} \mathrm{ASH}_{8}$ & $\mathrm{C}-\mathrm{S}-\mathrm{H}$ gels & Mica & LDH & $\mathrm{C}_{4} \mathrm{AH}_{13}$ \\
\hline $\mathrm{Na}_{2} \mathrm{O}$ & n.d. & $2.48 \pm 0.07$ & $2.37 \pm 0.18$ & n.d. & n.d. \\
$\mathrm{MgO}$ & n.d. & $1.91 \pm 0.21$ & $1.88 \pm 0.22$ & n.d. & n.d. \\
$\mathrm{Al}_{2} \mathrm{O}_{3}$ & $34.04 \pm 1.88$ & $25.58 \pm 0.43$ & $32.32 \pm 1.35$ & $26.04 \pm 0.92$ & $34.48 \pm 1.33$ \\
$\mathrm{SiO}_{2}$ & $28.31 \pm 1.63$ & $34.09 \pm 1.18$ & $47.10 \pm 2.05$ & $40.39 \pm 0.67$ & $1.65 \pm 0.06$ \\
$\mathrm{~K}_{2} \mathrm{O}$ & $0.82 \pm .0 .76$ & $2.02 \pm 0.07$ & $3.07 \pm 0.54$ & n.d. & n.d. \\
$\mathrm{CaO}$ & $29.76 \pm 0.66$ & $28.40 \pm 1.59$ & $6.06 \pm 0.41$ & $33.56 \pm 0.89$ & $63.87 \pm 1.11$ \\
$\mathrm{TiO}_{2}$ & n.d. & n.d. & $0.91 \pm 0.11$ & n.d. & n.d. \\
$\mathrm{Fe}_{2} \mathrm{O}_{3}$ & $7.07 \pm 0.47$ & $5.50 \pm 3.25$ & $6.27 \pm 0.82$ n.d. & n.d. & \\
\hline $\mathrm{Total}^{100}$ & 100 & 100 & 100 & 100 & 100 \\
\hline
\end{tabular}

The notation "n.d." indicates not detected.

the samples with substitution due to moderate pozzolanic activity.

The chemical analysis by EDX of the phases at 28 days of reaction is presented in Table 5.

\section{Conclusions}

Different residues have been used (coal mining, paper sludge and waste from a drinking water treatment plant) activated at $600^{\circ} \mathrm{C}$ for $2 \mathrm{~h}$ to elaborate blended cements.
According to the Frattini test the only blended cement that can be considered as pozzolanic is the one elaborated with the addition of $20 \% \mathrm{ACW}$.

Hydrated calcium aluminate and LDH compounds are favoured with the addition of ACW. LDH compounds with the addition of APS + FA and stratlingite appeared in the $\mathrm{ACW}$ and ASW.

The value of compressive strength for blended cements with $20 \%$ replacement is very close to that obtained for OPC paste, although higher values were obtained with the addition of $20 \%$ ACW. 
Due to the reduction of pores and because of the growth of hydrated compounds that have hydraulic properties, the compressive strength increases. Porosity decreases as a consequence of the formation of hydrated phases during pozzolanic reaction.

Data availability. No data sets were used in this article.

Author contributions. RVdlVM analysed the XRD and SEM data; RGG wrote the paper and analysed the XRD and SEM data; IVR performed the experiments; LFC analysed the FT-IR data; SMR analysed the TG and DTA data; MF designed the study.

Competing interests. The authors declare that they have no conflict of interest.

Special issue statement. This article is part of the special issue "European Geosciences Union General Assembly 2018, EGU Division Energy, Resources \& Environment (ERE)". It is a result of the EGU General Assembly 2018, Vienna, Austria, 8-13 April 2018.

Acknowledgements. The authors wish to express their gratitude and sincere appreciation to the Spanish Ministry of the Economy and Competitiveness under coordinated projects BIA2015-65558C3-1-2-3R (MINECO/FEDER) for financing this research work. We are grateful to the Sociedad Anónima Hullera Vasco-Leonesa (Spain) and to the Spanish Cement Institute (IECA) for their assistance with this research.

Edited by: Michael Kühn

Reviewed by: two anonymous referees

\section{References}

Bai, J., Chaipanich, A., Kinuthia, J. M., O’Farrell, M., Sabir, B. B., Wild, S., and Lewis, M. H.: Compressive Strength and Hydration of Waste Paper Sludge Ash Ground Granulated Blast furnace Slag Blended Pastes, Cem. Concr. Res., 33, 1189-1202, 2003.

De La Torre, A. G., Bruque, S., and Aranda, M. A. G.: Rietveld quantitative amorphous content analysis, J. Appl. Crystallogr., 34, 196-202, 2001.

Frías, M., Rodríguez, O., García, R., and Vegas, I.: Influence of Activation Temperature on Reaction Kinetics in Recycled Clay Waste-Calcium Hydroxide Systems, J. Am. Cer. Soc., 91, 40444051, 2008.

Frías, M., Vigil, R., Sánchez de Rojas, M. I., Medina, C., and Juan Valdés, A.: Scientific aspects of kaolinite based coal mining wastes in pozzolans $/ \mathrm{Ca}(\mathrm{OH})_{2}$ system, J. Am. Cer. Soc., 95, 386-391, 2012.

Frías, M., Vigil de la Villa, R., de Soto, I., García, R., and Baloa, T. A.: Influence of activated drinking-water treatment waste on binary cement-based composite behavior: Characterization and properties, Comp. Part B, 60, 14-20, 2014.

García, R., Vigil, R., Rodríguez, O., and Frías, M.: Study of hydrated phases present in calcined paper sludge (metakaolinite)/saturated $\mathrm{CaO}$ dissolution system cured at $40^{\circ} \mathrm{C}$ and 28 days of reaction, Mat. Sci. Eng. A-Struct., 527, 3936-3941, 2010.

García-Giménez, R., Vigil de la Villa Mencía, R., Rubio, V., and Frías, M.: The transformation of coal-mining waste minerals in pozzolanic reactions of cements, Minerals, 6, 64-70, 2016.

Gonçalves, A., Esteves, A., and Carvalho, M.: Incorporation of Sludges From a Water Treatment Plant in Cement Mortars, in: Inter. Conference on the Use of Recycled Materials in Building and Structure, edited by: RILEM, Vol. 1, Barcelona, Spain, 347350, 2004.

Husillos, N., Martínez, S., Blanco, M. T., Guillen, M., Puig, J., Larrotcha, E., and Flores, J.: Re-use of Drinking Water Treatment Plant (DWTP) Sludge: Characterization and Technological Behaviour of Cement Mortars with Atomized Sludge Additions, Cem. Concr. Res., 40, 778-786, 2010.

Janotka, I., Puertas, F., Palacios, M., Kuliffayova, M., and Varga, C.: Metakaolin sand Blended Cement Pastes: Rheology, Hydration Process and Mechanical Properties, Const. Buil. Mat., 24, 791802, 2010.

Kynci, M.: Opportunities for water treatment sludge re-use, Geo. Sci. Eng., 54, 11-22, 2008.

Pesce, G. L., Bowen, C. R., Rocha, J., Sardo, M., Allen, G. C., Walker, P. J., Denuault, G., Serrapede, M., and Ball, R. J.: Monitoring hydration in lime-MK composites using electrochemical impedance spectroscopy and nuclear magnetic resonance spectroscopy, Clay Min., 49, 341-358, 2014.

Ptacek, P., Frajkorova, F., Soukal, F., and Opravil, T.: Kinetics and mechanism of three stages of thermal transformation of kaolinite to metakaolinite, Powder Tec., 264, 439-445, 2014.

Rios, C. A., Williams, C. D., and Fullen, M. A.: Hydrogarnet and Tobermorite at $175^{\circ} \mathrm{C}$ from Kaolinite and Metakaolinite in the $\mathrm{CaO}-\mathrm{Al}_{2} \mathrm{O}_{3}-\mathrm{SiO}_{2}-\mathrm{H}_{2} \mathrm{O}$ System: A Comparative Study, Appl. Clay Sci., 43, 228-237, 2009.

Rodríguez, O., Sánchez de Rojas, M. I., García, R., and Vigil, R.: Effect of thermally activated paper sludge on the mechanical properties and porosity of cement pastes, Mat. Constr., 59, 1728, 2009.

UNE-EN 197-1: Cement, Part 1. Composition, specifications and conformity criteria for common cements, 2011.

UNE-EN 196-5: Methods of testing cement - Part 5: Pozzolanicity test for pozzolanic cement, 2011.

UNE-EN 450-1: Fly ash for concrete - Part 1: Definition, specifications and conformity criteria, 2013.

Vejmelkova, E., Pavlikova, M., Kepprt, M., Kersner, Z., Rovnanikova, P., Ondracek, M., Sedlmayer, M., and Cerny, R.: High Performance Concrete with Czech Metakaolin: Experimental Analysis of Strength, Toughness and Durability Characteristics, Constr. Buil. Mat., 24, 1404-1411, 2010.

Vigil, R., Frías, M., Sánchez de Rojas, M. I., Vegas, I., and García, R.: Mineralogical and Morphological Changes of Calcined Paper Sludge at Different Temperatures and Retention in Furnace, Appl. Clay Sci., 36, 279-286, 2007. 